\title{
Deformation of the Carboniferous on the Oldenburg High and the Location of the Variscan Front in Northwest Germany
}

\section{H. von Hartmann}

Institut für Geophysik, TU Clausthal, Arnold-Sommerfeld-Straße 1, D-38678 Clausthal-Zellerfeld, Germany;

e-mail: hartwig.vonhartmann@tu-clausthal.de

Received: February 2001; accepted: January 2002

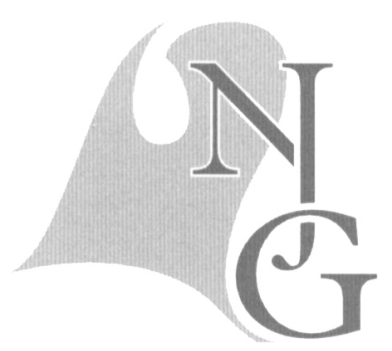

\begin{abstract}
The article tries to answer the question of the origin and structural development of the deformation of the pre-Permian units southwest of Bremen. An interpretetion of a 3D-seismic survey was made to resolve the structural style of the Upper Carboniferous with the aim to get some clues for the Variscan deformation of the Variscan foreland. The area is suitable for the evaluation because of the existence of a 3D-seismic survey. Moreover, the depth of the Zechstein at. $4500 \mathrm{~m}$ is not to deep for imaging deeper reflections and there is not a severe distortion of the reflection pattern by later tectonic developments. Because of the 3D insight into the complex and deep seated structures, other 2D-seismic investigations which image similar parts can be better understood and interpretation errors can be avoided. It is concluded that only 3D-seismic measurements can resolve the complex structural devolopment at this site.
\end{abstract}

Keywords: 3D- Seismic, Graben, Karbon, Northwest Germany, Rotliegend, Variscan Front

\section{Introduction}

The subject of investigation was the development of the Upper Carboniferous in the foreland basin of the Variscides in Northwest Germany. Seismic surveys carried out by the German oil and gas industry gave insight into the structural style of the Permian and pre-Permian units. The seismic survey is located southwest of Bremen in the exploration area Harpstedt on the Oldenburg High (Fig. 1). The size of the survey is $20 \times 20 \mathrm{~km}^{2}$.

The deformation style and its relationship to the Variscan collision remained an unsolved question.

The Northwest German Carboniferous Basin is part of the foreland basin of the Northwest European Variscides. Their foreland basin reaches from Ireland, England, Germany to as far as Poland. The origin of the basin is probably the result of two processes: The flexure of the subducted plate and a pull down effect by astenospheric flow beneath the basin (Gayer et al. 1993, Maynard et al. 1997).

The generally northward directed movement of the deformation front affected the southern parts of the basin (W. Franke et al. 1990).

In the the Belgian and French parts of the foreland the deformation front can be traced on the basis outcrops and seismic investigations (Bois et al. 1994, Meissner 1996). In Northwest Germany the deformation front starts at the „Aachener Thrust' which is a continuation of the Fault du Midi and continues to the northern parts of the Muensterland. East of the Muensterland it splits into two branches according to two different interpretations (Fig. 1):

- A northern line strikes the Oldenburg High southwest of Bremen and turns into an east-west direction (Lockhorst et al. 1998, Gerling et al. 1999). 


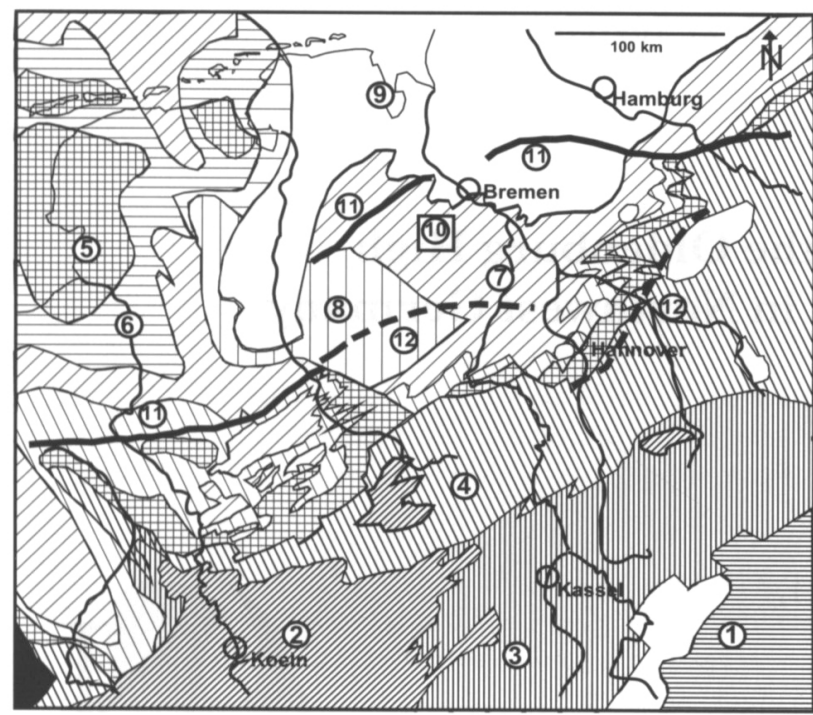

Fig. 1. Simplified Pre-Permian subcrop map of Northwest Germany after Lockhorst et al. (1998). 1 Mid crystalline rise, 2 Devonian, 3 Dinantian, 4 Namurian, 5 Westphalian A, 6 Westphalian B, 7 Westphalian C, 8 Westphalian D, 9 Stephanian, 10 Location of the 3D seismic survey, 11 suggested location of the Variscan front (Lockhorst et al. 1998), 12 suggested location of the Variscan front after Franke D. (1990).

- A southern line jumps at a transition zone towards the south and continues with a northeast direction (D. Franke 1990).

In the West German parts of the Variscan foreland, different deformation styles of the Variscan front can be recognized. Near the Brabant Massif the deformation front is marked by a prominent thrust zone. In the northern part of the Ruhr District the deformation becomes weaker towards the northwest. Here, the deformation style is characterized by broad synclines and small anticlines, combined with upthrusts (W. Franke et al. 1990). The continuation of the Variscan deformation and its style towards the north is speculative and a point of continued discussion. Within the Northwest German Basin the Carboniferous is covered by a thick layer of Mesozoic and Cenozoic units. This area was subsequently affected by different tectonic events such as salt movements, basin development, and inversion. In this part of the basin the Carboniferous deformation was not yet resolved. In the southern part of the Pompeckjsche Block, the tectonic overprint during the Mesozoic and Cenozoic had been less than in the Lower Saxony Basin and should allow the investigation of the deformation style of the Carboniferous units and their relationship to the Variscan foreland deformation.

\section{Geology}

The geological history of the survey area for the preCarboniferous has to be correlated to the margins at the North German Basin (D. Franke 1995, Hedemann et al 1984). All data which give insight into sedimentary and tectonic processes of the Carboniferous within the Northwest German Basin were gathered by the exploration industry by means of drilling and seismic results. Whereas early studies were performed mainly by the analysis of well logs (Hedemann et al. 1984) more recent work was supported by seismic surveys. Some of these data were used to establish a general view of the basement of the Northwest German area (Dohr 1989). The following view was generated.

During the Devonian and Lower Carboniferous an epicontinental platform was established south of the European Caledonides. Marine and terrestrial conditions alternate in the succession (Paproth 1988).

The Upper Carboniferous represents a foreland situation of the German part of the Variscides. There are no hints for small scale variations in thickness of the Upper Carboniferous strata (Hedemann 1984). In Westphal B and C coalbearing sequences were formed, separated by marine transgressions. The Stefanian shows the continuation of the subsidence and concurrent clastic sedimentation. Deformations of the Upper Carboniferous are partially related to the Variscan orogen, e.g. the Ruhr District and the northern part of the Muensterland.

The Lower Permian was dominated by extensional processes which are traced by volcanic activity and graben formation (Gast 1988). The grabens were filled during the Rotliegend. At this time the southern margin of the German part of the South Permian Basin was divided by depressions and swells which can be inferred from thickness variations of the sedimentary cover. The area surveyed in this paper is located on the Oldenburg High which was bordered in the west by the Ems depression and in the east by the Hessian depression (Walter 1995).

In the Triassic and Jurassic tectonic evolution regional trough and basin formation played a dominant role in Northwest Germany. The area surveyed is situated on the Pompeckjsche Block which formed a regional high that lasted from Malm to Lower Cretaceous. Further south the Lower Saxony Basin was inverted during the Upper Cretaceous. The Tertiary showed an overall regular subsidence.

In large areas of Northwest Germany the level above the Zechstein was locally modified by salt tectonics. The viscous flow of the evaporites to some extent uncoupled movements above and below the Zechstein strata. The interaction between movements of the levels below and above the Zechstein is therefore difficult to resolve and restricts the dating of tectonic events. 
The survey area is less effected by strong salt movements, regional subsidence and inversion tectonics. Therefore the tectonic style of the lower unit could be imaged to a large extent by the $3 \mathrm{D}$-seismic survey restricted to a depth of about $8000 \mathrm{~m}$ beneath the surface.

\section{Data}

The seismic survey consists of perpendicular inlines and crosslines which have a trace distance of $25 \mathrm{~m}$ in each direction. The seismic data were processed up to 5 seconds as a 3D-poststack time migration. The data quality above the Zechstein base is good and the number of interpretable reflections beneath the Zechstein is remarkably high in contrast to $2 \mathrm{D}$ lines in this area.

Four wells within the survey area reached up to 200 $\mathrm{m}$ into pre-Permian units. Gamma ray logs and cores have been used to correlate the strata within the Carboniferous units. A dip $\log$ is also available for one well, for the other three only core discriptions from well reports are available.

$2 \mathrm{D}$ lines are also available in this area but could not be used in interpreting the pre-Zechstein units. This was recognized by comparing $2 \mathrm{D}$ lines with the $3 \mathrm{D}$ survey. The reason is the higher signal to noise ratio of 3D-seismic survey and the complex structure beneath the Zechstein. This effect is amplified by the high impedance contrast between the salt and anhydrite of
Zechstein and the overlaying Triassic strata.

\section{Interpretation}

Fig. 2 shows a structural map of the 3D-survey. The isotime lines mark reflections within Westphalian units which could be traced best. Reflections within the Carboniferous mostly show no lateral coherency. The characteristic style of single reflections varies laterally, thus the interpretation was guided by typical reflection groups and homogenous dip of reflection areas. The use of an interactive interpretation system helped by an iterative approach tracing homogenous parts of the Carboniferous units. Tracing a specific horizon across faults is therefore difficult. The analysis of vertical displacements at faults was done by means of detailed reflection patterns and characteristic features which were not necessarily part of the interpreted horizon.

Strong reflection events mark the coal bearing sequences within the Westphalian B and C. The interpreted region of the $3 \mathrm{D}$-survey splits into different parts which are separated by faults. The isolines give an overview of the dip and structural separation of the Carboniferous. Prominent faults were active within the post-Zechstein. Seismic lines had to be choosen which gave the best view of the structural elements, i.e. parallel and perpendicular to the axes of the structures.
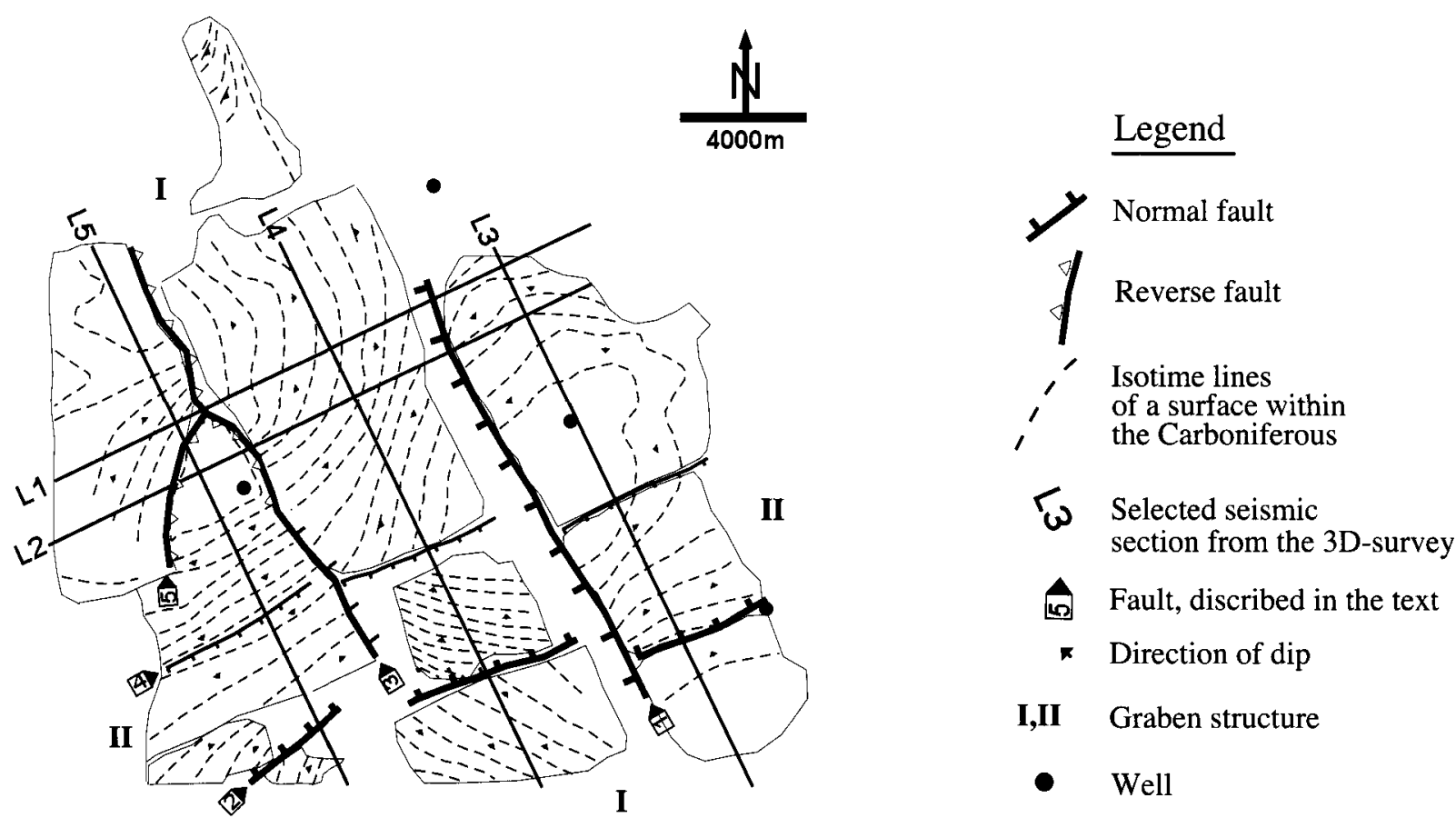

Fig. 2. Structural map of the Upper Carboniferous units traced by reflection elements of Westphalian B and C within the survey area. Isolines of two way traveltime (TWT) drawn as stippled lines were $67 \mathrm{~ms}$ apart and reach from 2.4 to 3.8 seconds TWT. L1 to L5 marks selected lines shown in in figures 4 to 6 . The filled points localize the four wells reaching Carboniferous units and the boxed numbers mark lineaments which characterize the grabens I and II. 


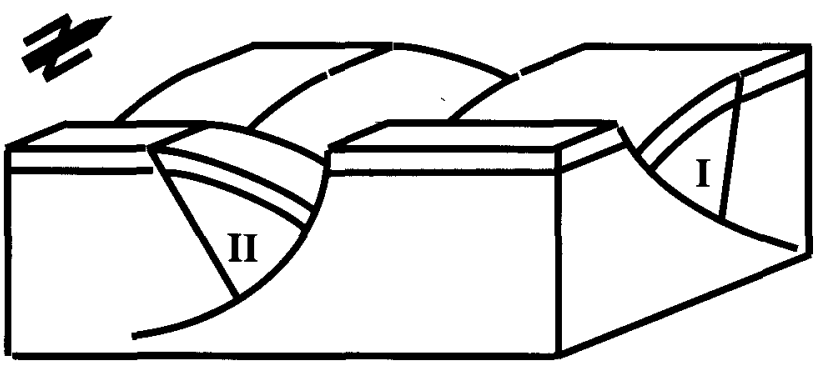

Fig. 3. Model of two intersecting grabens. The generalized model can explain the dips and structural elements found within the Carboniferous units.

After the structural style had been resolved, a stratigraphic interpretation was added with information from log data. The distribution of the four wells is shown on the structural map (Fig. 2).

Within the seismic profiles homogeneous reflection zones can be defined which are separated by imaginary lines which show a slight convex or concave curvature. The reflections within the area are mostly straight with varying coherency and amplitude.

From vertical diplacements and the dip of the reflections zones it was concluded that the overall tectonic style is anarrangement of two grabens which intersect nearly perpendicular (Fig. 3). The interpretation was acompanied by comparing investigations of extensional structures from the literature (Gibbs 1984, Rowan and Kligfield 1989,Xiao and Suppe 1992, Williams and Vann 1987). Geometrical expres- sions exist for the relationship between different parts of the hanging wall and the normal fault. These methods use an idealized style of extensional deformation but demonstrate the relationship of the different elements (Groshong 1989). Experimental approachs showed the development of the internal deformation of the hanging wall due to the inclination and form of the normal fault (Withjack et al. 1995). It showed a rotation of the shear faults. These pictures give a more realistic view of the deformation. A geologic examples from Colorado Plateau reveal the whole complexity and may hint to other processes which were not included into the numerical and physical examples (Hamblin 1965).

The interpretation resulted in the following: (Fig. 2): The survey is devided by five main lineaments. 1 and 2 which mark the two master faults of the half grabens I and II. 3 and 4 are the corresponding faults within the hanging walls and 5 possibly belongs to a neighbouring graben system to the west. The faults 3 and 5 had been partially reactivated as reversed faults in a subsequent compressional event.

A north-northeast fault (fault 5, Fig. 2) in the southwest corner of the area and a northwest striking fault (fault 3, Fig. 2) define a triangular structural high of the Zechstein units, which remains visible up to the Cretaceous. Northwest of this zone the border of the seismic survey prohibit a definitive interpretation of the seismic image.

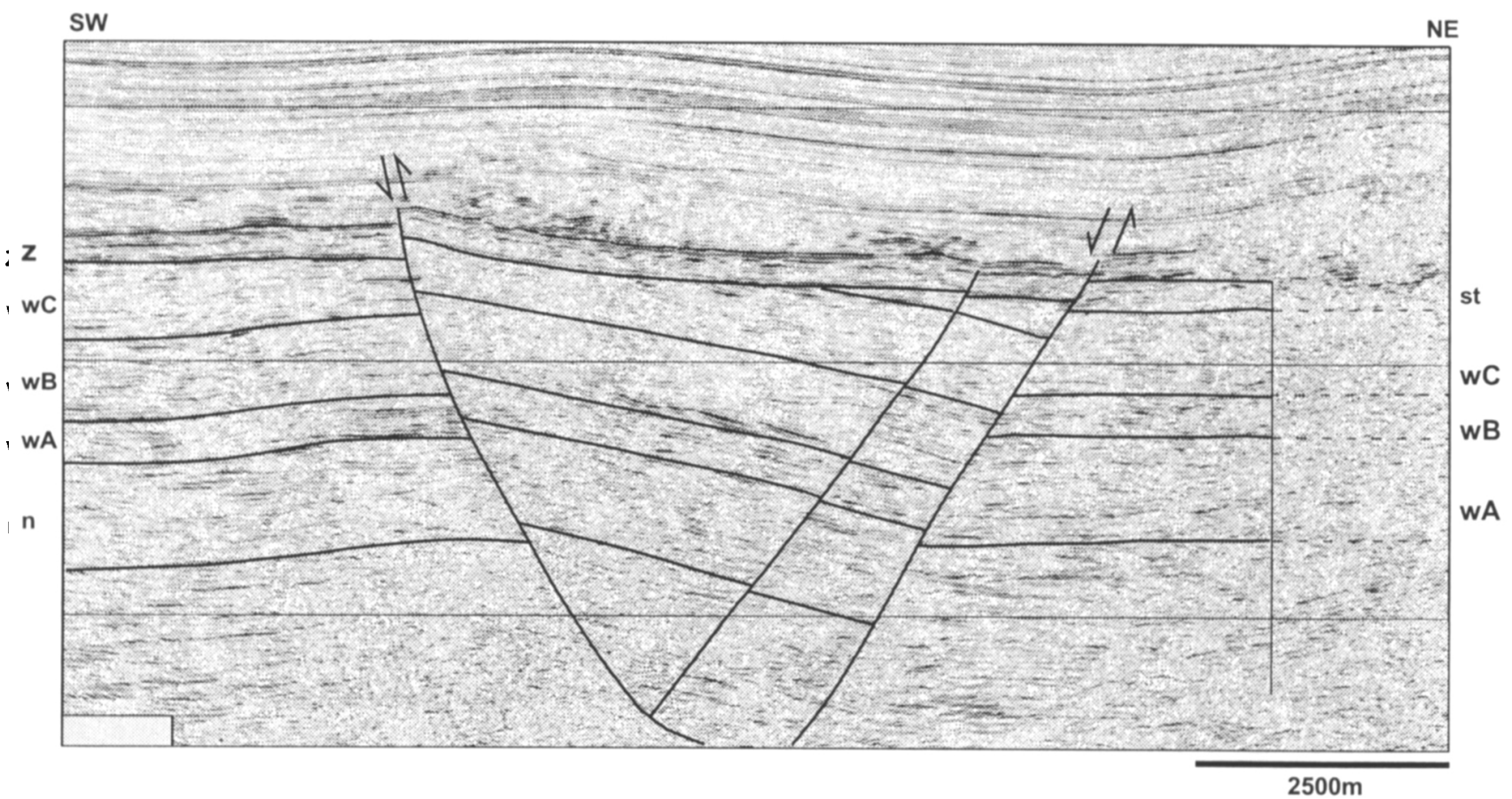

Fig. 4. Line 1, selected line within the 3D seismic survey area, for the location see Figure 2. It shows the halfgraben I with it's normal fault located in the northeast. The former fault on the southwest side was activated by an upthrust by a later probably Cretaceous event. Superimposed are the borders of stratigraphic units: z Zechstein, st Stephanian, wC - wA Westphalian C - A, n Namurian, TWT :Two way traveltime in seconds. 
Seismic line 1 (Fig. 4, Fig. 6a) runs in southwest/ northeast direction. It cuts graben $I$ perpendicular near the northern border of the triangle zone. The interpretation shows the structure of the Carboniferous units from Namurian to Westphalian and also the Zechstein base. Dipping reflections with a component in northeast direction belong to the hanging wall of graben $\mathbf{I}$. The normal fault (1, Fig. 6a) which separates the dipping from the horizontal reflections in the northeast footwall is relatively straight. A possible listric curvature of the faults in not observed due to the two way travel time limit of five seconds and the poorly defined seismic reflections in the lower parts of the seismic sections. The fault $(3$, fig. $6 \mathrm{a})$ in the southwest which separates the active part of the hanging wall from the passive one changed to a reverse fault in post-Zechstein time. Strong reflections caused by anhydrite layers within the Zechstein were shifted and serve as indicators for the deformation in the postZechstein time. Northeast of the terminations of this fault within the Zechstein, part of the Triassic has been faulted probably due to the same event. A second fault running parallel to the first in the southwest led to a small adjustment within the Carboniferous and to shifting of reflections within the Zechstein.

Line 2 (Fig. 6 b) runs parallel to line 1 and cuts the triangle zone in its northern part. The central part of this line is similar to line 1 . The dipping reflections belong to the hanging wall of graben $\mathbf{I}$. Within the footwall in the northeastern part of the section a com- pressional event in the post-Zechstein can be deduced from two faults cutting Zechstein and Buntsandstein units. Further to the east margin a salt accumulation restricts the interpretation of the preZechstein in this direction. The structural high which marks the triangular zone in the southwest of the survey area is clearly identified by vertical offsets within Zechstein and Carboniferous. Parts of the Buntsandstein have also been included in the deformation. The structural high of the triangular zone is marked off by two reverse faults dipping in northeast and southeast directions. The fault 3 marks in this part the southwest dipping reverse fault as the prominent feature. It cuts the former fault of graben $I$ and forms the borders of two reverse faults in the southwest.

Line 3 (Fig. 5, Fig 6c) runs in southeast direction perpendicular to graben II. The normal fault (2, Fig. $6 c)$ of the graben dips in northwest direction. A second fault (2a, fig. $6 \mathrm{c})$ further to the northwest divides areas of different dips without a prominent shifting of the reflection patterns. Conjugate faults which dip in opposite directions led to an additional division of the hanging wall. The faults separating the active and passive area of the hanging wall cannot be recognized as clearly as in the lines further to the west. This is possible due to an upthrusting of this part of the area, which can be detected from a shifting of Zechstein reflections. A thrusting is clearly visible in the southeastern part of the seismic profile (Fig. 5) A curved fault cuts the normal fault of the graben and shifts the

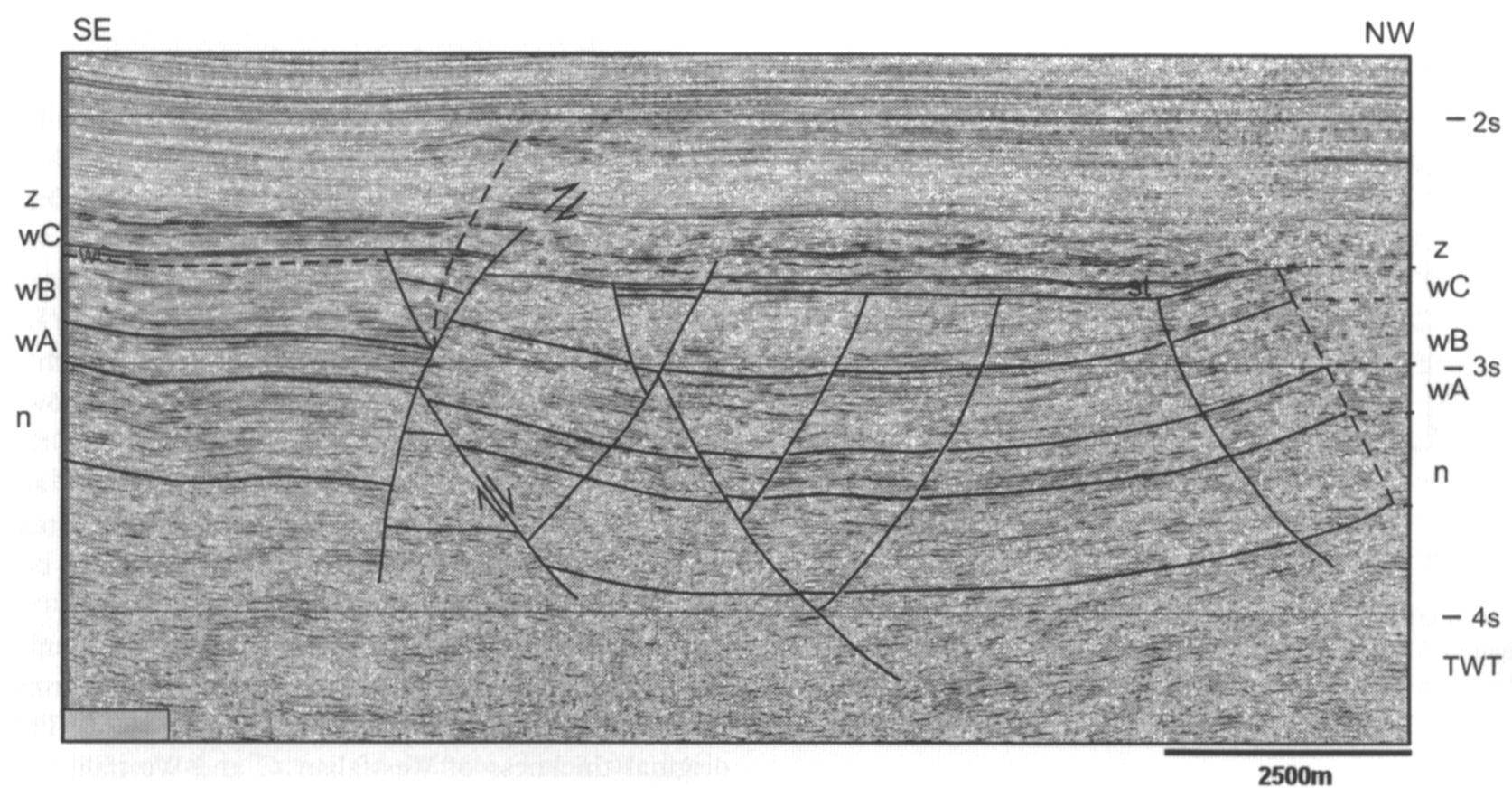

Fig. 5. Line 3, selected line within the 3D seismic survey area, for location see figure 2 . The line runs parallel on the footwall of graben I an cuts graben II perpendicularly. The normal fault on the southeast side have been severely affected by an upthrust of the former footwall of the graben II. For the stratigraphic terms see figure 4 . 

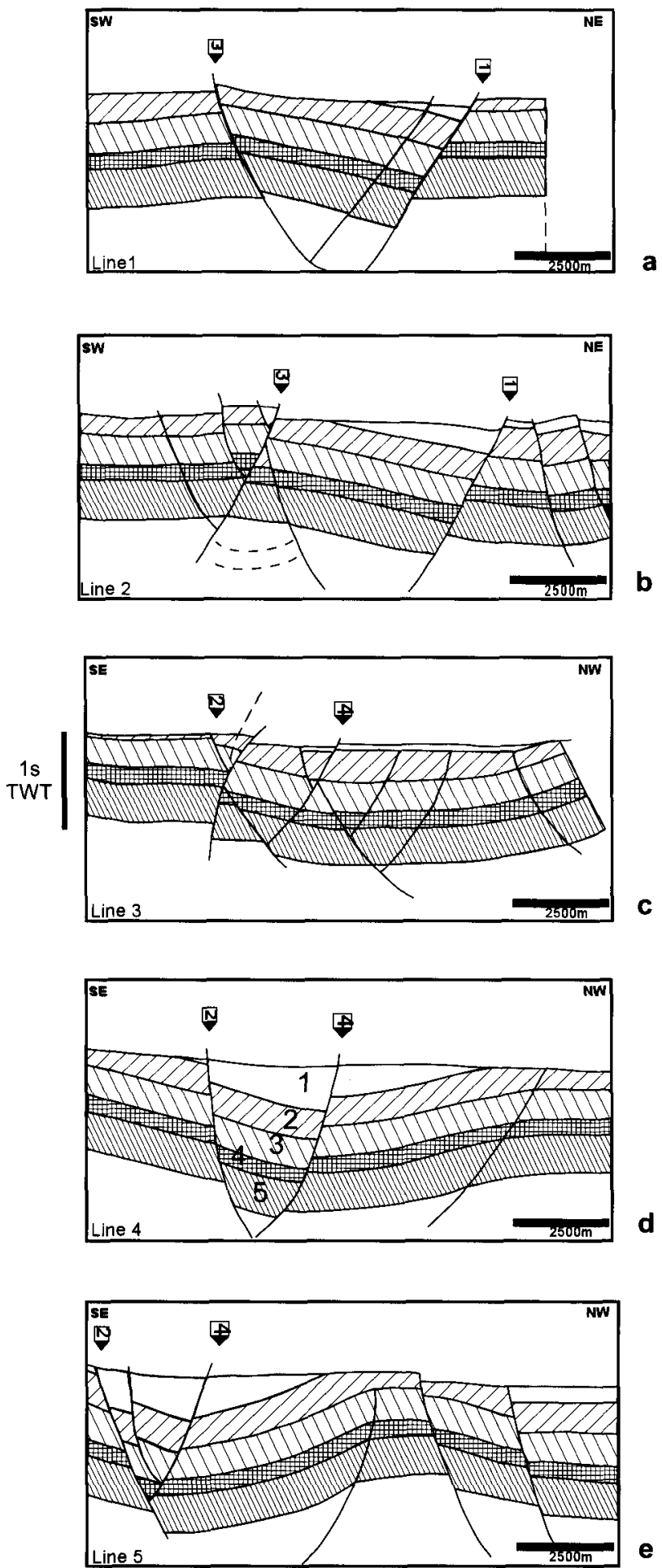

Fig. 6. Interpretation of the five selected seismic profiles of the 3Dseismic survey. The location of the lines is shown in figure 2. 1 Stephanian, 2 Westphalian C, 3 Westphalian B, 4 Westphalian A, 5 Namurian. $a$ and $b$ run perpendicular to graben $I, c-e$ perpendicular to graben II. The boxed numbers mark faults as it shown in figure 2. The upper border of the interpreted units is formed by the Zechstein base. For the interpretation of the five seismic profiles see part 4: Interpretation.

former footwall slightly over the former hanging wall. The deformation can still be followed up within the Buntsandstein.
Line 4 (Fig. 6d) runs parallel line 3 in southwest direction. The profile is placed within the hanging wall of graben I and shows the geometry of a half graben with the master fault $(2$, fig. $6 \mathrm{~d})$ in the southeast similar to line 3. The part adjacent to the normal fault was thrown down to a greater amount than the parts further to the northwest. This movement is associated with a lowering of the Zechstein base. In this part of the graben II a later upthrusting as shown in the neighbouring lines 3 and 5 is not visible.

Line 5 (Fig. 6e) runs further to the southwest and cuts the triangular zone in southeastern direction. The normal fault of graben II is placed at the southeast end of the profile. The adjacent parts to the northwest show a complex and differential downthrusting and partial upthrust. The Zechstein base above this area also shows a small pull down effect similar to line 4 . Northwest of the faults separating passive and active parts, two normal faults belong to an adjacent graben to the west. The structure cannot be entirely interpreted close to the border of the 3Dseismic coverage of the area.

The stratigraphic interpretation is a generalisation from only a few hints from the correlation of the well logs with Carboniferous strata. Nevertheless, with the available information it was possible to draw a consistent picture of the distribution of the Upper Carboniferous units within the complex area. The stratigraphy is interpreted by correlation of gamma ray logs of the various members of the Westphalian and Stephanian units., The different gamma ray signatures of sand- and mudstones, coal measures and marine transgressions helped to assign the petrophysical patterns to the stratigraphic system.

Four wells reached pre-Zechstein units, one on the top of the southwestern triangular zone, the other one on the the eastern graben shoulder of graben II. Only two wells drilled Rotliegend. Within the area the Rotliegend has a thickness of less than the seismic resolution, therefore it was not included into the interpretation. It is suggested that Rotliegend with a larger thickness is preserved within the downthrown parts of the graben system. In the eastern part of the survey area the uppermost Carboniferous layers are Stephanian in age. In the western part the Zechstein base overlies Westphalian C. Stephanian was not deposited or has been entirely eroded.

The wells drilled less than $200 \mathrm{~m}$ into the Carboniferous. The remaining thickness was estimated from former investigations by Hedemann et al. (1984). The original thickness of Westfalian C and Westfalian B were taken to be $800 \mathrm{~m}$ for each unit, Westfalian $\mathrm{A}$ $400 \mathrm{~m}$, and Namurian $1000 \mathrm{~m}$.

The penetrated Carboniferous layers consist mostly 
of alternating mud- silt and sandstones. The dip amount of the units were taken from core interpretations of well reports and one dip log. The dip was less than 15 degree in three wells. In the dip log a structural dip of 20 degree over the length of $80 \mathrm{~m}$ within the Carboniferous was interpreted. The dipping zone also extends into the overlying Rotliegend. A correlation of the dips and the seismic data is not possible because of the poor data quality beneath the Zechstein reflectors.

\section{Discussion}

The survey area was affected by several tectonic events. The timing of these events can only be determined in a broad sense because of the uncoupling between the upper and lower level due to the evaporites and an erosional event before the Zechstein transgression.

The youngest deformation which affects the Paleozoic units occured during the Upper Cretaceous. The Zechstein upthrust in the southwestern part can still be recognized within the Dogger sediments. Other events, which suggest a post- Zechstein compression, are affected by halokinetic movements which compensate a part of the basement uplift. The vicinity to the Lower Saxony Tectogen to the south indicates a link to Upper Cretaceous inversion tectonics.

The northwest southeast striking faults ( 1 and 3, Fig. 2) show the same direction as the Rotliegend graben east of the survey area. Therefore, these structures should be regarded as the same tectonic system as the Rotliegend graben system in the southern part of the Southern Permian Basin. The small amount of Rotliegend and Stephanian strata that has been drilled indicates a later uplift followed by erosion of the area before the Zechstein transgression. The geological development during the Rotliegend can therefore be only concluded from the structure of the graben system.

Two grabens could be interpreted (Fig. 7) which intersect each other almost perpendicular. High reflection regions in the Westphalian show no lateral variation in thickness. The reflections just beneath the Zechstein show a diffusive pattern, probably due to the high impedance contrast between the Zechstein and adjacent units. Therefore no indications were seen for a synsedimentary development within the upper parts of the graben. The interpretation of the two half grabens is consistent with the reflection pattern of the whole area. In the northern part of the area horizontal reflections dominate. These are built up by short reflections. It is not clear whether two grabens were formed by a succession of two extensional events or by a transpressional event.
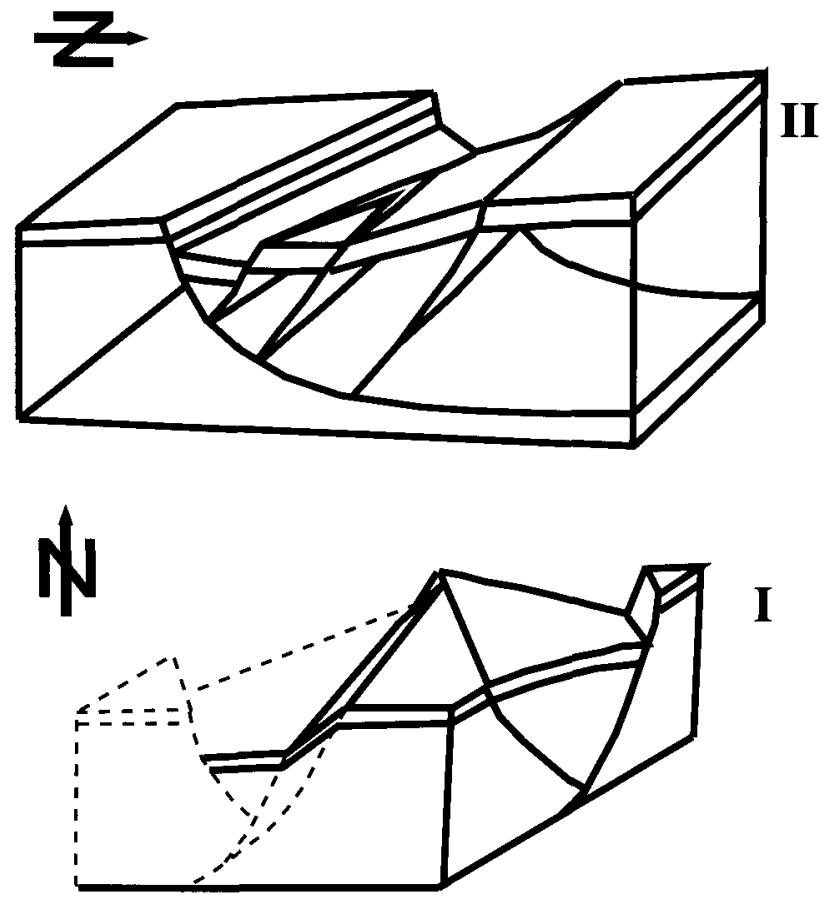

Fig. 7. Two models of grabens I and II respectively which show the main elements. The models show the geometry if no intersections had occured. The stippled lines mark an adjacent graben which could not be interpreted because of the margin of the survey area.

Rotliegend graben systems (Gast, 1988, 1991) are situated east of the interpreted survey area. Another graben was described from the Southern North Sea (Quirk \& Aitken 1993).

These tectonic developments were not part of the structural evolution of the Variscan foredeep but mark the beginning of the Permian Basin.

Pre-Permian compressional structures were not found in the survey area. An interpretation as synclines and anticlines do not agree with the coeval fault pattern and the vertical thrust of reflection units. Further investigations to the east and south also showed little evidence for a Variscan deformation. Therefore, a more southern location of the Variscan front as suggested by Franke et al. (1990) is more realistic than a location of the front within the Bremen - Hamburg area.

The seismic interpretation showed that a sufficient resolution of the post-Zechstein units only can be achieved by using 3D-data. The reflection patterns of 2D-seismic lines are affected by side effects and do not necessarily run perpendicular to the strike direction of the structural elements.

\section{Conlusions}

By tracing the reflection groups within the Upper Carboniferous across faults a complex graben system was identified with two grabens which intersect each 
other almost perpendicular. The deformations which could be resolved fit very well with the interpretation of a graben system that resides on the southern margin of the South Permian Basin (Gast, 1988). The Upper Cretaceous inversion tectonics of the Lower Saxony Tectogen south of the survey area led to some compressional features reactivating older elements. A compressional event that can be linked to a Variscan foreland deformation could not be found. The reflection pattern outside the graben was more or less horizontal or dips conformably with post-Zechstein units. Further investigations of seismic surveys of adjacent areas show similar structural elements of grabens. A Variscan front is, therefore, suggested to be located further to the south (Fig. 1), a suggestion which is supported by the hypotheses of Franke et al. (1995).

\section{Acknowledgements}

We acknowledge the companies of the W.E.G., especially BEB Erdgas and Erdoel GmbH. The study is part of the project 'Orogenic Processes' of the Deutsche Forschungsgemeinschaft, carried out in a cooperation of the Geological Survey of Lower Saxony (NLfB) and the Geophysical Institute of the Technical University Clausthal. The discussions with F. Binot and M. Pasternak (NLfB) were very helpful getting a closer look into the Northwest German Basin and Loesch (NLfB) clarified stratigraphic correlation. The discussions with R.E. Gast (BEB) were very helpful to view the results in a greater framework.

\section{References}

Bois, C., Cazes, P., Choukroune, O., Gariel, O., Hirn, A., LeGall, B., Lefort, J.P., Matte, P., Pinet, B., 1994. Seismic Reflection Images of the Pre-Mesozoic Crust in France. In: Keppie, J.,D. (ed.): Pre-Mesozoic Geology in France and related Areas. Springer Verlag (Berlin): $3-48$

Dohr, G., 1989. Ergebnisse geophysikalischer Arbeiten zur Untersuchung des tieferen Untergrundes in Norddeutschland. In: Niedersächsische Akademie der Geowissenschaften Heft 2: Das Nordeutsche Becken: Geophysikalische und geologische Untersuchungen des tieferen Untergrundes. (Hannover): 4-22

Franke, D., 1990. Geologisch-Strukturelle Karte des Präperm von Mitteleuropa 1: 1500000, Berlin, Zentrales Geologisches Institut Franke, D., 1995. The North Variscan Forland, In: Dallmeyer, R.,D., Franke, W., Weber, K.(eds.): Pre-Permian Geology of Central and Eastern Europe. Springer Verlag (Heidelberg): 554593

Franke, W., Bortfeld, R.,K., Brix, M., Drozdzewski, G., Dürbaum, H., J., Janoth, W., Jödicke, H., Reichert, C. , Scherp, A., Schmoll, J., Thomas, R., Thünker, M., Weber, K., Wiesner, M.G., Wong,
H., K., 1990. Crustal structure of the Rhenish Massif: results of deep seimic reflection lines DEKORP 2-North and 2-North-Q. Geologische Rundschau 79: 523-566

Gast, R., E., 1988. Rifting im Rotliegend Niedersachsens. Die Geowissenschaften 6: 115-122

Gast, R., E., 1991. The Perennial Rotliegend Saline Lake in Northwest Germany. Geologisches Jahrbuch Reihe A 1 19: 25-59

Gayer, R., A., Cole, J., E., Greilling, R., O., Hecht, C. , J., Jones, A., 1993. Comparative Evolution of Coal Bearing Foreland Basins along the Variscan Northern Margin in Europe. In: Gayer, R., A. (ed.): Rhenohercynian and Subvariscan Fold Belts. Vieweg (Braunschweig): 47-82

Gerling, P., Kockel, F., Krull, P., 1999. Das Kohlenwasserstoffpotential des Präwestfal im Norddeutschen Becken - Eine Synthese. DGMK-Forschungsbericht 433, Hannover, 107

Gibbs, A.D., 1984. Structual evelution of extensional margins. Journal of the geological Society of London 141: 609-620

Groshong ir., R., H., 1989. Half-graben structures: Balanced models of extensional fault-bend folds. The American Association of Petroleum Geologists Bulletin 101: 96-105

Hamblin, W.,K., 1965. Origin of reverse drag on the downthrown side of normal faults, Geological Society of America Bulletin 76: 1145-1164

Hedemann, H.-A., Schuster, A., Stancu-Kristoff, G., Lösch, J., 1984. Die Verbreitung der Kohlenflöze des Oberkarbons. In: Fortschritte in der Geologie von Rheinland und Westfalen 32: Nordwestdeutschland und ihre stratigraphische Einstufung. Geologisches Landesamt Nordrhein-Westfalen (Krefeld): 39-88

Lockhorst, A., Adlam, K., Brugge, J., David, P., Diapari, L., Fermont, W., J., J., Geluk, M., Gerling, P., Heckers, J., Kockel, F., Kotarba, M., Laier, T., Lott, G., K., Milaczewski, E., Milaczewski, L., Nicholson, R.,A., Platen, F., V., Pokorski, J., 1998. European Gas Atlas - Composition and Isotope Ratios of Natural Gases CD-ROM, ISBN: 90-72869-60-5

Maynard, J., R., Hofmann, W., Dunay, R., E., Bentham, P., N., Dean, K., P., Watson, I., 1997. The Carboniferous of western Europe: the development of a petroleum system. EAPG, London, Petroleum Science 3: 97-115

Meissner, R., 1996. Faults and folds, facts and fiction. Tectonophysics 264: 279-293

Paproth, E., 1988. Die paläogeografische Entwicklung Mittel-Europas im Karbon. Geologisches Jahrbuch Hessen 117:53-68

Quirk, D.G. , Aitken, J.A. , 1997. The structure of the Westphalian in the northern part of the southern North Sea. In: Ziegler, K., Turner, K., Daines S.,R. (eds.): Petroleum geology of the southern North Sea: Future Potential. Geological Society Special Publication No. 123: 143-152

Rowan, M.G. and Kligfield R., 1989. Cross section restoration and balancing as aid to seismic interpretation in extensional terranes. The American Association of Petroleum Geologists Bulletin 73: 955-966

Walter, R., 1995. Geologie von Mitteleuropa. Schweitzerbart'sche Verlagsbuchhaltung. (Stuttgart): $565 \mathrm{pp}$

Williams, G. and Vann, I., 1987. The geometry of listric faults and deformation in their hanging walls. Journal of Structual Geology, 9: 789-795

Withjack, M.O., Islam, Q.T., La Pointe, P.R., 1995. Normal faults and their hanging wall deformation: An experimental study. The American Association of Petroleum Geologists Bulletin 79: 1-18

Xiao, H. and Suppe J., 1992. Origin of Roll Over. The American Association of Petroleum Geologists Bulletin 76:509-529 